\title{
Seasonal incidence of apple leaf miner (Lyonetia clerkella (L., 1758), Lepidoptera, Lyonetiidae) in Kashmir, India
}

\author{
Sumiulah RATHER ${ }^{1,2}$, Abdul A. BUHROO ${ }^{1}$, Abdul Lateef KHANDAY $^{1}$
}

Received April 28, 2019; accepted April 29, 2020.

Delo je prispelo 28. aprila 2019, sprejeto 29. aprila 2020.

\begin{abstract}
Seasonal incidence of apple leaf miner (Lyonetia clerkella (L., 1758), Lepidoptera, Lyonetiidae) in Kashmir, India

Abstract: The seasonal incidence of apple leaf miner ( $L y$ onetia clerkella [L., 1758], Lepidoptera, Lyonetiidae) was investigated in four districts of Kashmir valley from March 2015 to April 2016. The prevalence of infestation was found higher in Srinagar (70.6\%) and Bandipora (65.3\%) as compared to Pulwama (9.3\%) and Baramulla (6.6\%). Infestation intensity was found at its peak during the month of May (2015) in all the four districts. In Srinagar, the percent infestation intensity during May (2015) was found to be $58.69 \%$ ( \pm 11.46 SD), while as in Bandipora, Pulwama and Baramulla, it was found as $55.71 \%$ ( $\pm 12.59 \mathrm{SD})$, $6.04 \%( \pm 1.97 \mathrm{SD})$ and $4.27 \%( \pm 1.12 \mathrm{SD})$ respectively. Infestation of intensity was observed to decline linearly from the first week of June (2015) and disappeared completely with the beginning of winter season. Further, seven generations of L. clerkella were found under laboratory conditions. The $1^{\text {st }}, 2^{\text {nd }}, 3^{\text {rd }}, 4^{\text {th }}, 5^{\text {th }}$, and $6^{\text {th }}$ generations completed in 39, 40, 37, 39, 45 and 48 days respectively. However, final generation $\left(7^{\text {th }}\right)$ was found relatively longer in duration, extended from the $4^{\text {th }}$ week of September (2015) till April of the following year (2016) for about 204 days. In general, the life cycle of $L$. clerkella is similar to those described for other leaf miner species.
\end{abstract}

Key words: Lyonetia clerkella; prevalence; infestation intensity; seasonal history
Sezonsko pojavljanje sadnega listnega zavrtača (Lyonetia clerkella (L., 1758), Lepidoptera, Lyonetiidae) v Kašmirju, Indija

Izvleček: Sezonsko pojavljanje sadnega listnega zavrtača (Lyonetia clerkella (L., 1758), Lepidoptera, Lyonetiidae) je bilo preučevano $\mathrm{v}$ štirih območjih doline Kašmirja od marca 2015 do aprila 2016. Razširjenost okužbe je bila večja v Srinagarju (70,6 \%) in Bandipori (65,3 \%) v primerjavi s Pulwamo (9,3\%) in Baramullo (6.6 \%). Velikost okužbe je dosegla višek v maju (2015) v vseh štirih območjih. V Srinagarju je bil odstotek okužbe, v maju 2015 58,69 \% ( \pm 11,46 SD), medtem, ko je bil v Bandipori, Pulwami in Baramulli 55,71 \% ( $\pm 12,59$ SD), 6,04 \% ( $\pm 1,97$ SD) in $4,27 \%$ ( $\pm 1,12$ SD). Velikost okužbe je linearno upadala od prvega tedna $\mathrm{v}$ juniju (2015) in je popolnoma izginila $\mathrm{z}$ začetkom zimske sezone. V laboratorijskih razmerah je bilo ugotovljenih sedem generacij sadnega listnega zavrtača. Prva, druga, tretja, četrta, peta in šesta generacija so zaključile svoj razvoj po $39,40,37,39,45$ in 48 dneh. Zadnja, sedma generacija, je imela daljši razvoj, ki je trajal od četrtega tedna v septembru 2015 do aprila 2016, skupno okrog 204 dni. V splošnem je življenski krog sadnega listnega zavrtača podoben tistim, ki so opisani za ostale vrste listnih zavrtačev.

Ključne besede: Lyonetia clerkella; raširjenost; velikost okužbe; sezonsko pojavljanje

1 University of Kashmir, Section of Entomology, Postgraduate Department of Zoology, Hazratbal, Srinagar, India

2 Corresponding author, e-mail: samiullahento1@gmail.com 


\section{INTRODUCTION}

Kashmir is famous for the deliciousness of its temperate fruits in every part of India (Rather \& Buhroo, 2015). Thousands of fruit orchards consisting mainly of apple (Malus domestica Borkh) can be seen in many parts of the valley. However, a wide variety of insect pests also occur on apple trees from the onset of foliage till the end of autumn period. Among these pests, apple leaf miner (Lyonetia clerkella (L., 1758) is regarded as one of the most common, widespread and destructive in many parts of the valley (Ahmed \& Bhat1987; Rather \& Buhroo, 2015).

The female moths of L. clerkella deposit their eggs singly into the leaf parenchyma (Adachi, 1998). The larvae feed on mesophyll immediately after being hatched. Thereafter, the hatched caterpillars form serpentine mines in the upper half of leaves that are visible to the unaided eyes. However, leaf epidermis is not damaged during the mesophyll devouring and larvae occupy mines till the next phase of their life cycle. The mines with variable lengths that range from narrow linear galleries to wide chambers appear as whitish or grey areas on the leaves. Mines excavated by the larvae of $L$. clerkella were found to be one of the major causes that reduce the photosynthetic capacity of leaves and cause their premature abscission (Spencer, 1973; Parrella, 1987; Parrella \& Jones, 1987). The larval tunneling has also been reported to provide a way for the pathogens to enter into the tissues of the plants (Zitter \& Tsai, 1977) and decline the annual yield of fruits (Wolfenbarger, 1954; Ledieu \& Heyler, 1985; Minkenberg \& Van Lenteren, 1986).

The re-emergence of hibernated moths of L. clerkella occurs with the flowering of apple trees. As the day temperature rises in spring, male and female population of these moths emerge in about the equal numbers (Faeth,
1985). After arrival, these miner insect pests target the leaves of the host plants. The female moths discriminate and select the suitable leaves for oviposition. Leaf selection is therefore an important aspect as far as insect-plant interactions are concerned (Faeth et al., 1981).

There is no information available on the prevalence and intensity of infestation of this miner pest in the Indian sub-continent. Therefore, the aim of the present study was to investigate the various aspects of L. clerkella including prevalence, infestation intensity and the number of generations.

\section{MATERIAL AND METHODS}

In order to evaluate the infestation prevalence of $L$. clerkella in different districts of Kashmir such as Srinagar (34 51'.161” N, 74 47’ 50.535” E, Elev. 1,585 m asl) Bandipora ( $34^{\circ} 41^{\prime} 670^{\prime \prime} \mathrm{N}, 74^{\circ} 68^{\prime} 69.425^{\prime \prime}$ E, Elev. 2,183 $\mathrm{m}$ asl) Pulwama (33 $52^{\prime} 18.627^{\prime \prime} \mathrm{N}$ and $74^{\circ} 53^{\prime} 57.753^{\prime \prime}$ E, Elev. 1,740 $\mathrm{m}$ asl) and Baramulla (34 $12^{\circ} 72.732^{\prime \prime} \mathrm{N}$, $74^{\circ} 20^{\prime} 53.732^{\prime \prime}$ E, Elev. 1,615 $\mathrm{m}$ asl) (Fig. 1), three sites in each of these districts were selected.

Fifty host trees (Malus domestica 'Red Delicious') at each site were surveyed during the peak season (May 2015) of this pest. Number of infested trees at each site was counted. Percent prevalence of infestation for every district was calculated by the following formula:

$$
\frac{\text { Total No. of infested trees in three sites of a district }}{\text { Total No. of trees at these sites }} \times 100
$$

For assessing the infestation intensity in the various months of a year (2015), three sites in every district (Srinagar, Bandipora, Pulwama and Baramulla) were

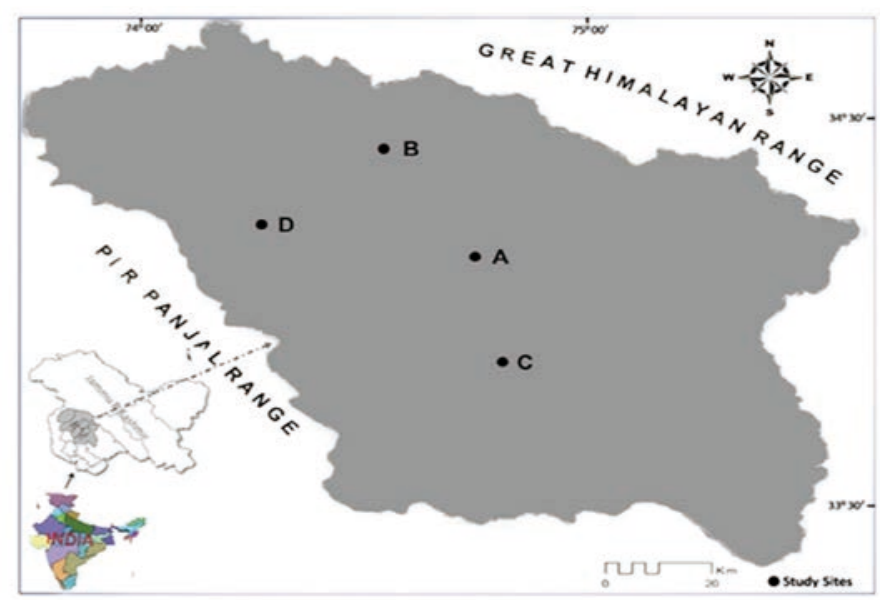

Figure 1: Map showing sampling sites $(\mathrm{A}=$ Srinagar, $\mathrm{B}=$ Bandipora, $\mathrm{C}=$ Pulwama and $\mathrm{D}=$ Baramullah $)$ 
selected. The sampling was done as per the method adopted by Adachi (2002). Five infested trees at each site were surveyed randomly at every survey during the final week of every month, from April to December (2015). One branch from each of these host trees at every site was chosen and the total number of leaves (fresh and mined) and mines of this branch were counted. Infestation intensity for each district was thereafter calculated by the following formula:

\section{$\frac{\text { Total number of infested leaves in three sites }}{\text { Total number of mines they bear }} \times 100$}

In order to determine the number of generations $L$. clerkella produces under laboratory conditions, methodology adopted by Rather and Buhroo (2015) was followed. Leaves carrying cocoons of this pest were collected from the field and brought in the laboratory. Small sections of these leaves with cocoons were incised and placed inside the 7 litre transparent plastic bottles mounted upon the 2.5 feet apple plants (Figs. 2-3). These bottles had cross ventilations with the dimensions of $10 \times 10 \mathrm{~cm}$ covered with one layer of nylon mesh for the free circulation of air. About 25-30 cocoons were introduced in each of these bottles. Dead moths of the first generation were collected for preservation and leaves were constantly being observed with the help of torch light (being placed on the underside of the leaves) and high power magnifying glass (Fig. 4). After the appearance of mines, bottles were again mounted on these experimental plants until the formation of cocoons. This process was repeated till the end of final generation. The duration of each generation was thereafter calculated from the time of oviposition till the death of adult moths.

Images were taken by Canon EOS 1200-D camera attached with Reynox super macro 250-D lens on a 75-250 mm zoom lens. Analysis of variance (ANOVA)
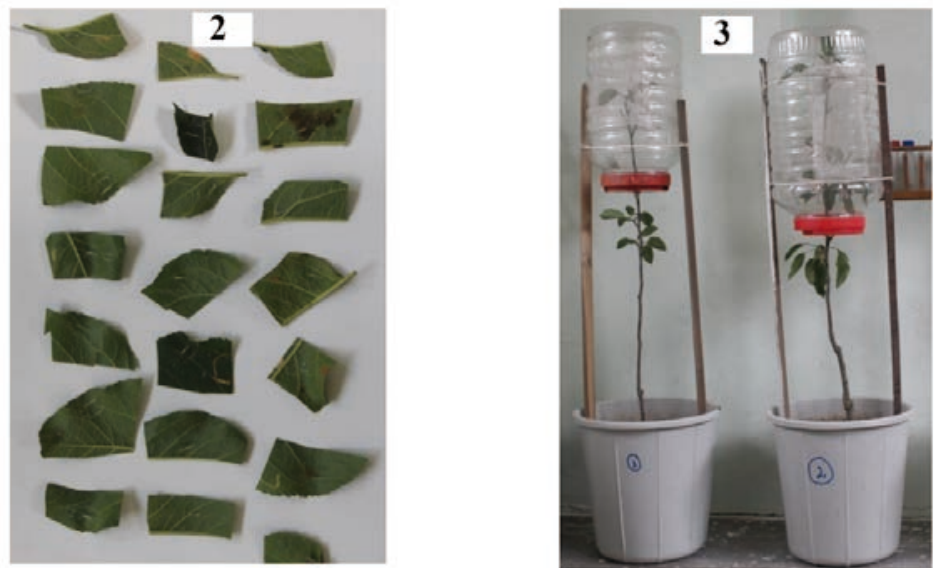

Figure 2 \& 3: 2 Leaf sections with cocoons 3. Bottles mounted on apple plants

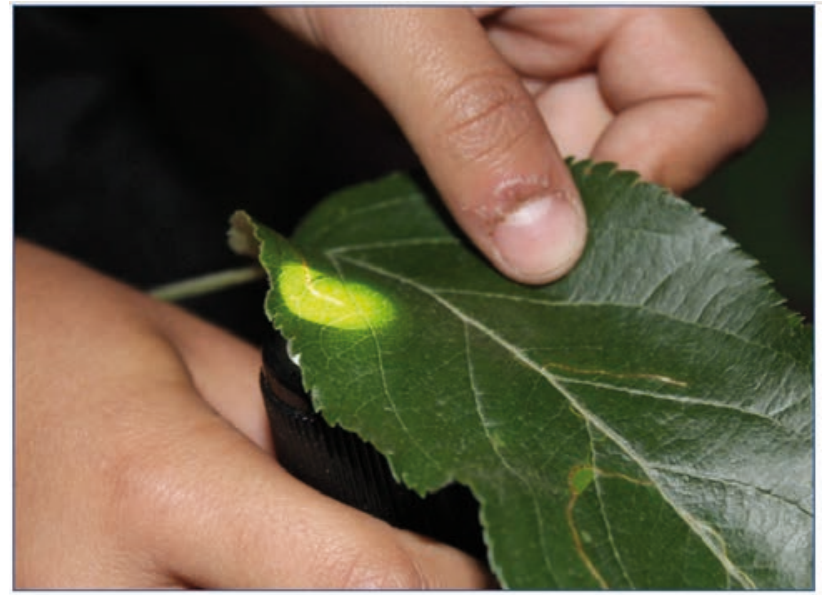

Figure 4: Mine observation by placing a torch at the inner side of a leaf 
followed by Tukey's multiple comparison test was done in SPSS (Version 20). The significance of differences between means was determined at $p<0.05$.

\section{RESULTS}

\subsection{PREVALENCE}

One hundred and six (70.6\%) out of 150 host trees in Srinagar were found infested with L. clerkella and 98 $(65.3 \%)$ trees were found infested in Bandipora (Fig. 5). The situation was quite different in the other two districts. Fourteen (9.3\%) trees in Pulwama and merely 10 (6.6\%) trees in Baramulla were found infested. No significant difference $(p>0.05)$ in infestation prevalence was found between Srinagar and Bandipora, and between Pulwama and Baramulla. However, this difference was found statistically significant $(p<0.05)$ between Srinagar-Bandipora and Pulwama-Baramulla districts (Fig. 5).

\subsection{INFESTATION INTENSITY}

The seasonal variation in infestation intensity (\%) in different districts of Kashmir is given in Table 1. The intensity of infestation was found relatively high in May
(2015) than the other months (April and June - December 2015) in all the study areas of the valley, Srinagar, Bandipora, Pulwama and Baramulla. However, the rate of infestation was found much more in intensity in Srinagar and Bandipora districts as compared to other two areas of the Valley (Pulwama and Baramulla). Although the signs of infestation appeared from the third week of April in all these districts, infestation was however found with varying intensities among them throughout the year. In the month of April, the intensity of infestation in Srinagar, Bandipora, Pulwama and Baramulla were calculated to be $7.61 \%$ ( $\pm 2.87 \mathrm{SD}$ ), $6.74 \%$ ( $\pm 2.36 \mathrm{SD}), 2.19 \%$ ( \pm $0.61 \mathrm{SD})$ and $1.01 \%( \pm 0.31 \mathrm{SD})$ respectively (Figs. 6-9). The percent infestation intensity of district Srinagar and Bandipora were found statistically similar but different than Pulwama and Baramulla (Table 1).

Infestation intensity was found at its peak during the month of May (2015) in all the four districts. In Srinagar, the percent infestation intensity was found to be 58.69 $\%$ ( \pm 11.46 SD) while as in Bandipora, Pulwama and Baramulla, it was calculated as $55.71 \%$ ( $\pm 12.59 \mathrm{SD}), 6.04 \%$ ( \pm $1.97 \mathrm{SD})$ and $4.27 \%( \pm 1.12 \mathrm{SD})$ respectively. The percent infestation intensity of district Srinagar and Bandipora are statistically similar but statistically different from Pulwama and Baramulla (Table 1).

The level of infestation intensity was observed to decline linearly from the first week of June till the last week

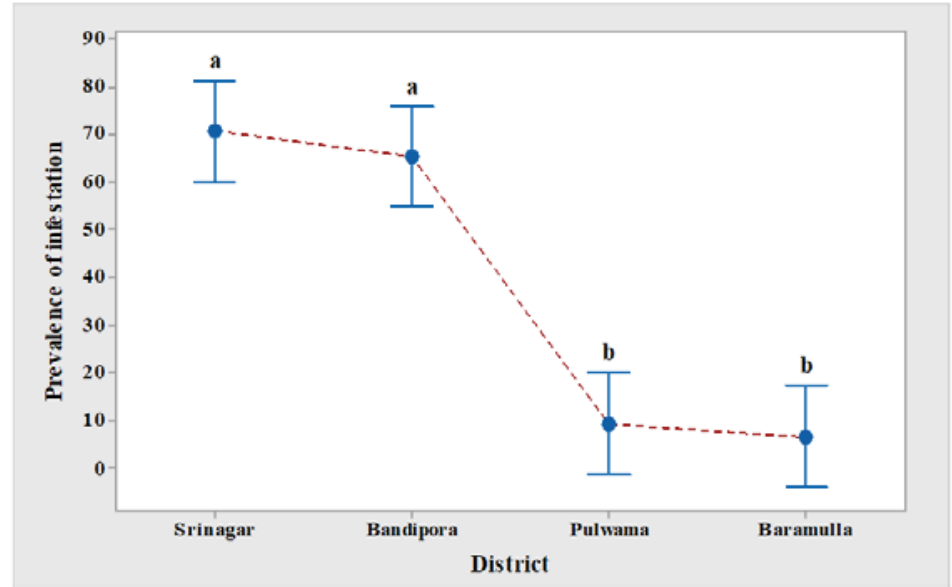

Figure 5: Prevalence of infestation in different districts of Kashmir

Table 1: One way ANOVA showing seasonal variation in infestation intensity (\%) in different districts of Kashmir (Mean \pm SD)

\begin{tabular}{|c|c|c|c|c|c|c|c|c|c|c|}
\hline District & March & Apr & May & June & July & Aug & Sep & Oct & Nov & Dec \\
\hline Srinagar & $0.00^{\mathrm{a}} \pm 0.00$ & $7.61^{\mathrm{a}} \pm 2.87$ & $58.69^{\mathrm{a}} \pm 11.46$ & $637.29^{a} \pm 16.19$ & $32.61^{\mathrm{a}} \pm 9.58$ & $27.07^{a} \pm 5.07$ & $13.43^{\mathrm{a}} \pm 6.28$ & $7.92^{\mathrm{a}} \pm 4.92$ & $3.73^{\mathrm{a}} \pm 1.36$ & $0.00^{\mathrm{a}} \pm 0.00$ \\
\hline Bandipora & $0.00^{\mathrm{a}} \pm 0.00$ & $6.74^{\mathrm{a}} \pm 2.36$ & $55.71^{\mathrm{a}} \pm 12.59$ & $47.07^{\mathrm{a}} \pm 17.08$ & $23.01^{\mathrm{a}} \pm 9.86$ & $8.17^{b} \pm 2.15$ & $6.55^{\mathrm{b}} \pm 1.10$ & $2.75^{\mathrm{b}} \pm 0.99$ & $1.22^{b} \pm 0.65$ & $0.00^{\mathrm{a}} \pm 0.00$ \\
\hline Pulwama & $0.00^{\mathrm{a}} \pm 0.00$ & $2.19^{b} \pm 0.61$ & $6.04^{b} \pm 1.97$ & $4.85^{b} \pm 0.49$ & $4.15^{\mathrm{b}} \pm 1.09$ & $4.16^{c} \pm 0.86$ & $4.49^{c} \pm 1.76$ & $1.80^{\mathrm{b}} \pm 0.81$ & $1.63^{b} \pm 1.30$ & $0.00^{\mathrm{a}} \pm 0.00$ \\
\hline Baramulla & $0.00^{\mathrm{a}} \pm 0.00$ & $1.01^{\mathrm{b}} \pm 0.31$ & $4.27^{\mathrm{b}} \pm 1.12$ & $4.40^{\mathrm{b}} \pm 0.61$ & $3.41^{\mathrm{b}} \pm 1.09$ & $2.45^{\mathrm{c}} \pm 0.3$ & $2.36^{\mathrm{c}} \pm 1.66$ & $2.58^{b} \pm 1.65$ & $1.23^{\mathrm{b}} \pm 0.65$ & $0.00^{\mathrm{a}} \pm 0.00$ \\
\hline
\end{tabular}




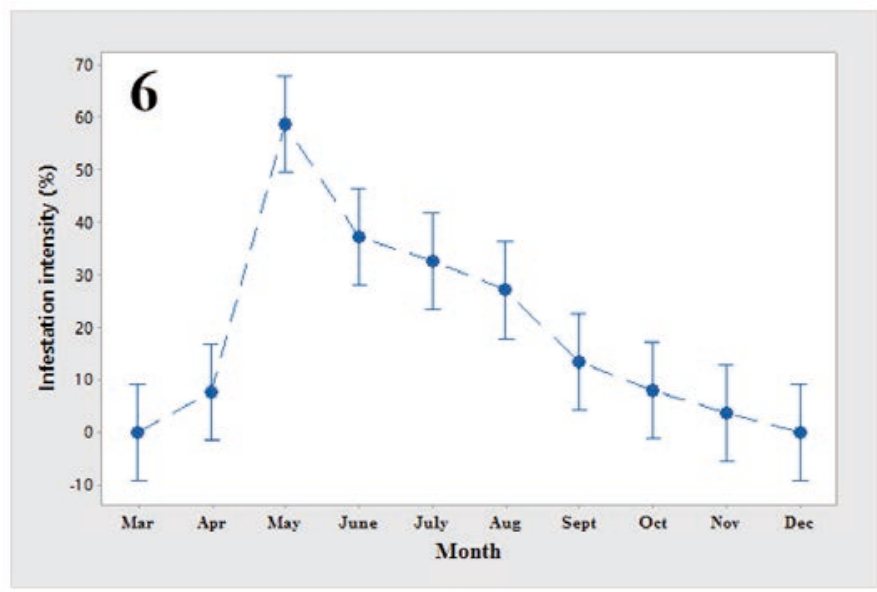

Figure 6: Infestation intensity in various months of a year; Srinagar

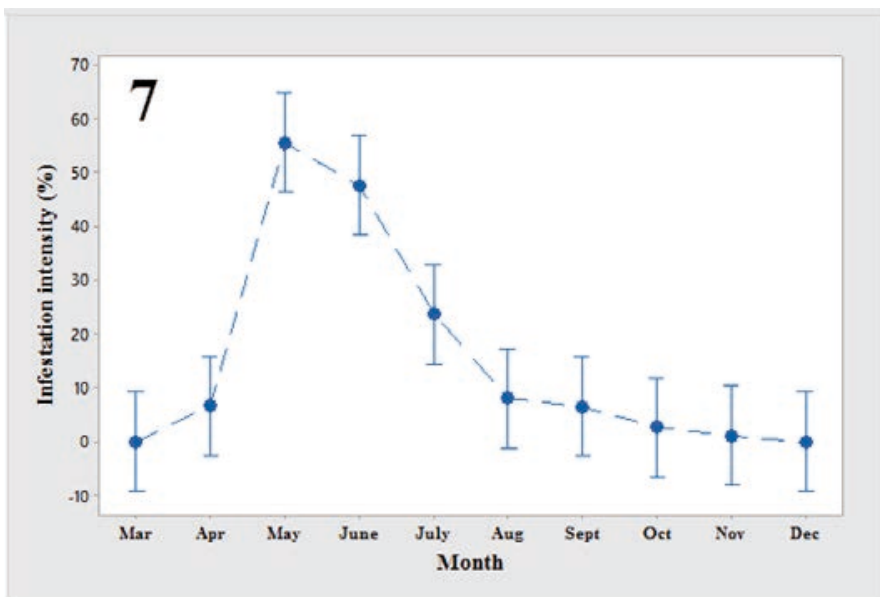

Figure 7: Infestation intensity in various months of a year; Bandipora

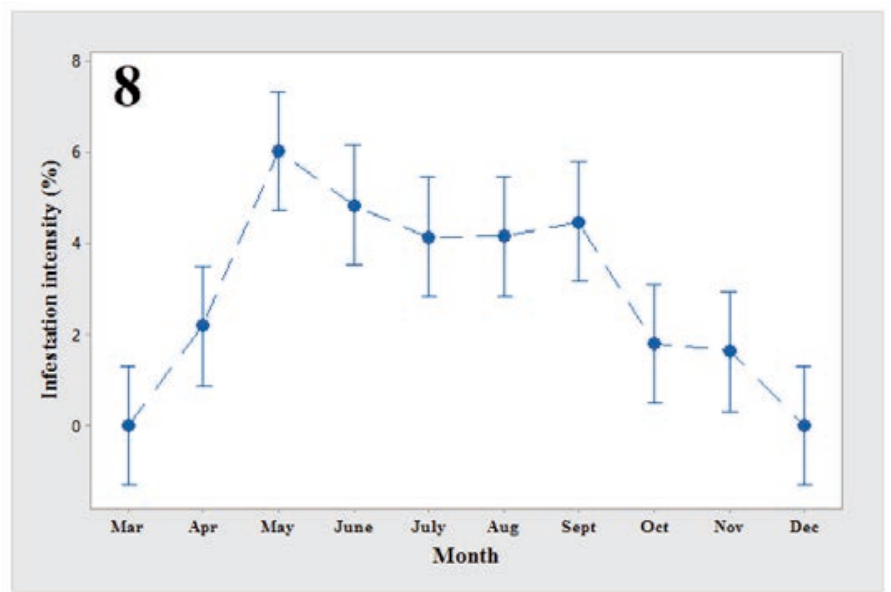

Figure 8: Infestation intensity in various months of a year; Pulwama 


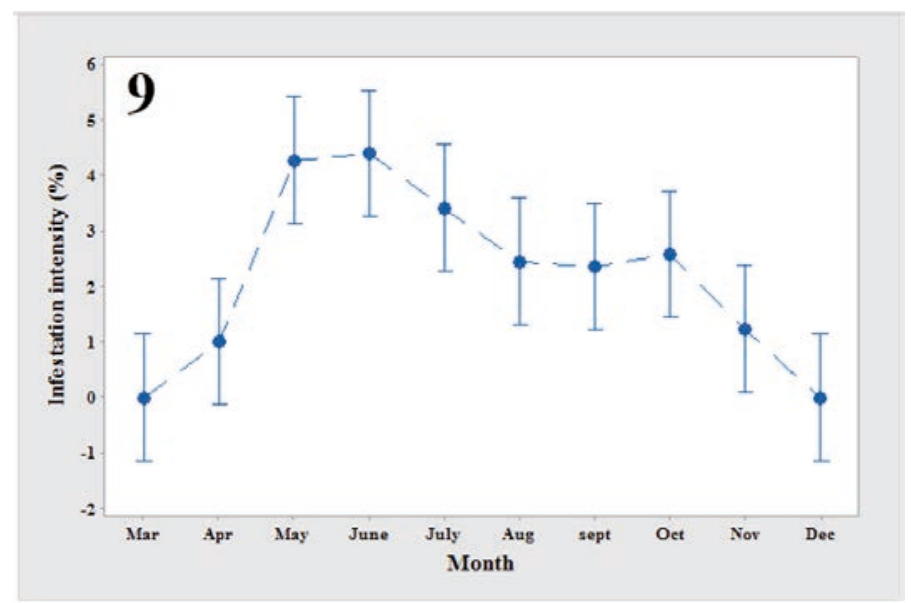

Figure 9: Infestation intensity in various months of a year; Baramulla

of November (2015). The intensity of infestation was found least in the month of November (2015). In Srinagar, infestation intensity in this month was calculated as $3.73 \%( \pm 1.36$ SD) while as in the other three areas of the valley, Bandipora, Pulwama and Baramulla, it was found to be $1.22 \%$ ( \pm 0.65 $\mathrm{SD}), 1.63 \%( \pm 1.30 \mathrm{SD})$ and $1.23 \%( \pm 0.65 \mathrm{SD})$ respectively. The percent infestation intensity of district Srinagar was found statistically different from all the other three areas.

\subsection{SEASONAL HISTORY}

Seven generations of $L$. clerkella were found in the laboratory (Fig. 10). First generation started from $12^{\text {th }}$ of April (2015) and ended on $20^{\text {th }}$ of May (2015). Second generation begin from $8^{\text {th }}$ of May (2015) and completed on $16^{\text {th }}$ of June (2015). Third generation commenced from $5^{\text {th }}$ June (2015) and ended on $11^{\text {th }}$ July (2015). Fourth generation begin from $27^{\text {th }}$ of June (2015) and completed on $4^{\text {th }}$ of August (2015). Fifth generation started from $21^{\text {st }}$ of July (2015) and ended on $3^{\text {rd }}$ September (2015). Sixth generation commenced on $21^{\text {st }}$ of August (2015) and completed on $7^{\text {th }}$ of October (2015). Similarly, $7^{\text {th }}$ generation extended from $24^{\text {th }}$ of September (2015) to mid spring (15 ${ }^{\text {th }}$ April) of the following year (2016). Moths of the final generation $\left(7^{\text {th }}\right)$ hibernated during the winter months, from $2^{\text {nd }}$ week of November (2015) till March of the following year ((2016) (Fig. 10).

Thus, the first, second, third, fourth, fifth, and sixth generations of $L$. clerkella completed in 39, 40, 37, 39, 45 and 48 days respectively. However, final generation $\left(7^{\text {th }}\right)$ was found relatively longer in duration, extended from the $4^{\text {th }}$ week of September (2015) till April of the following year (2016) for about 204 days.

The swarms of hibernated moths were first seen from $11^{\text {th }}$ to $20^{\text {th }}$ of April in the year 2015 and the average day temperature of this period was recorded to be $21{ }^{\circ} \mathrm{C}$ (Table 2). However in 2016, the swarms of these moths

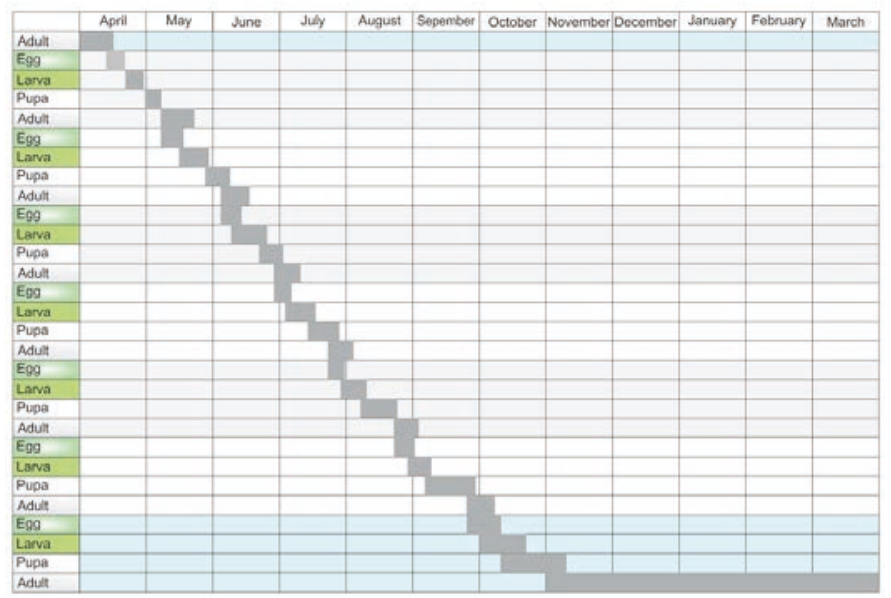

Figure 10: Seasonal history of L. clerkella as seen in laboratory 
were observed from $17^{\text {th }}$ to $25^{\text {th }}$ of April with an average day temperature of $21.4^{\circ} \mathrm{C}$.

\section{DISCUSSION}

In the present study, the prevalence and infestation intensity was found to fluctuate seasonally in different study areas (Srinagar, Bandipora, Pulwama and Baramulla) of the valley with relatively high level of prevalence and intensity being observed in the month of May. The highest prevalence was found in Srinagar and Bandipora districts $(70.6 \%$ and $65.3 \%)$. Similarly, the highest intensity of infestation was found in Srinagar, $58.69 \%$ ( \pm $11.46 \mathrm{SD})$ followed by Bandipora, 55.71 \% ( $\pm 12.59 \mathrm{SD})$ whereas, least infestation intensity was found in Pulwama $6.04 \%( \pm 1.97 \mathrm{SD})$ and Baramulla $4.27 \%( \pm 1.12$ $\mathrm{SD})$. A significant difference in infestation intensity was also observed among these four districts (Table 1). The variations in prevalence and infestation intensity among different districts of the valley (April to November 2015) could be attributed to the factors such as insecticides, parasitism, temperature and food quality as reported by Dixon (1987) and Feeny (1970).

These insect pests resume their activities in spring under varying temperatures at different places of the world (Kholchenkov, 1974). In Azerbaijan, Kholchenkov (1974) reported that L. clerkella appear in spring at the temperature of $12{ }^{\circ} \mathrm{C}$. However, in Kashmir, the swarms of hibernated moths of this pest were found to appear in early spring, between $11^{\text {th }}$ to $25^{\text {th }}$ of April at an average day temperature of $21.2^{\circ} \mathrm{C}$ (Table 2).

Since $L$. clerkella is widely distributed in many parts of the world, the number of generations subjected to specific temperatures and elevations were reported varying from place to place. Agata et al. (2007) reported three generations of $L$. clerkella at the altitude of $200-300 \mathrm{~m}$ and 1-2 generations at an elevation of 750-860 m. This pest was found to develop 3-4 generations per year in Ukraine (Kholchenkov, 1974). Furthermore, Shoji \& Ueno (1981) reported that the apple leaf miner moths grow for 5 to 6 generations per year in Yamagata Prefecture while as Miyaji (1991) found L. clerkella produced 9 generations per year in Kagoshima prefecture, Japan. Apple leaf miner was also found to produce 5 generations in a year under natural conditions in Kashmir (Rather \& Buhroo, 2015). The 7 generations in experimental room as observed in the present study fell within this expected range.

Relatively shorter duration of the first two generations (April to June) could be attributed to the availability of better food quality (Dixon, 1987). In the months of spring and early summer (April to June), the mesophyll content remains soft which enables the caterpillars to feed voraciously as compared to subsequent months when the available foliage dries and becomes relatively tougher due to the deposition of cellulose, hemicelluloses, pectins, and other materials (Feeny, 1970). Seasonal changes in the leaf tannin composition can also have an adverse impact on the generation time as increased tannin concentration negatively affects the growth of lepidopteron caterpillars (Varley \& Gradwell, 1962). The ability of tannins to form complexes with proteins enhances defense mechanism of plants and thereby affecting the growth of insects (Feeny, 1970).

The work of many authors indicated that the duration of puparial stage of apple leaf miner insects extends relatively from the onset of autumn period because of reduction in daily temperatures (Kholchenkov, 1974; Kuznetsov \& Seksyaeva, 1994; Savkovskii, 1976). In the present study, the puparial stage was also found comparatively longer in duration from the beginning of autumn season because of linear reduction in daily temperatures. The longevity of adult moths of this pest was also found to decrease with the decrease in temperature from the month of September.

\section{REFERENCES}

Adachi, I. (1998). Hymenopterous parasitoids of the peach leaf miner, Lyonetia clerkella (Linnaeus) (Lepidoptera: Lyonetiidae). Applied Entomology and Zoology, 33(2), 299-304. https://doi.org/10.1303/aez.33.299

Adachi, I. (2002). Evaluation of generational percent parasitism on Lyonetia clerkella (Lepidoptera: Lyonetiidae) larvae in peach orchards under different management intensity. Applied Entomology and Zoology, 37(3), 347-355. https://doi. org/10.1303/aez.2002.347

Agata, Z., Filipescu, C., Georgeseu, T., Talmaciu, N. \& Bernardis, R. (2007). Biology, Ecology and integrated control of the species Lyonetia clerkella: Pest in the apple plantation from Neamt County. Neamt County phytosanitary Board, pp. 1125-1128.

Ahmed, D. \& Bhat, M.R. (1987). Insect pests of apple trees in Kashmir. Geobios New Reports, 6, 60-63.

Dixon, A.F.G. (1987). Parthenogonetic reproduction and the rate of increase in aphids. In A. K. Minks and P. Harrewijn [eds.]. Aphids, their biology, natural enemies and control. Elsevier, Netherlands, 2, 269-287.

Faeth, H.S. (1985). Host leaf selection by leaf miners: interactions among three trophic levels. Dept of Zoology, Arizona state University. Ecology, 66(3), 870-875. https://doi. org/10.2307/1940549

Faeth, S. H., Mopper, S. \& Simberloff, D. (1981). Abundances and diversity of leaf-mining insects on three oak host species: effects of host-plant phenology and nitrogen content of leaves. Oikos, 37, 238-251. https://doi.org/10.2307/3544471

Feeny, F. (1970). Seasonal changes in Oak leaf tannins and nu- 
trients as a cause of spring feeding by winter moth caterpillars. Ecology, 51, 565-581. https://doi.org/10.2307/1934037

Kholchenkov, V.A. (1974). Family Lyonetiidae. In: Vasil. ev V. P., ed. Pests of agricultural crops and forest plantations. V.2. Arthropods. Kiev: Urozhai, pp. 230-231.

Kuznetsov, V.I. \& Seksyaeva, S.V. (1994). Family Lyonetiidae (Leucopteridae, Leucopterigidae, Cemiostomidae). In: Kuznetsov V. I., ed. Insects and mites. Pests of agricultural plants. V. 3 (1). Lepidoptera. St. Petersburg: Nauka, pp. 269-273.

Ledieu, M.S. \& Heyler, N.L. (1985).Observations on the economic importance of tomato leaf miner (Liriomyzabryoniae) (Agromyzidae). Agricultural Ecosystem \& Enviornment, 13, 103-109. https://doi.org/10.1016/0167-8809(85)900532

Minkenberg, O. \& Van Lanteren, J. (1986). The leaf miners Liriomyza bryoniae and L. trifolii (Diptera: Agromyzidae), their parasities and host plants: a review. Agricultural University Wagenigen Papers, 86, 1-50.

Miyaji, K. (1991). Seasonal prevalence of the peach leafminer, Lyonetia clerkella in Kagoshima prefecture [Japan]. Proceedings of the Association for Plant Protection of Kyushu (Japan), 37, 198-200. https://doi.org/10.4241/kyubyochu. 37.198

Parrella, M.P. \& Jones, V.P. (1987). Development of integrated pest management strategies in floricultural crops. Bulletin of the Ecological Society of America, 33, 28-34. https://doi. org/10.1093/besa/33.1.28

Parrella, M.P. (1987). Biology of Liriomyza. Annual Review of Entomology, 32(1), 201-224. https://doi.org/10.1146/annurev.en.32.010187.001221

Rather, S. \& Buhroo, A.A. (2015). Arrival sequence, abundance and host plant preference of the apple leaf miner Lyonetia clerkella Linn. (Lepidoptera: Lyonetidae) in Kashmir. $\mathrm{Na}$ ture and Science, 13, 25-31.

Savkovskii, P.P. (1976). Atlas of the pests of fruit and berry plants. Kiev. Urozhai, pp. 207.

Shoji, T. \& Ueno, W. (1981). Ecological studies on the peach leaf miner, Lyonetia clerkella, Life tables in the insecticideunsprayed orchard. Annual Report of the Society of Plant Protection of North Japan (Japan), 32, 46-51.

Spencer, K.A. (1973). Agromyzidae (Diptera) of economic importance. Springer Science \& Business Media, pp. 418. https://doi.org/10.1007/978-94-017-0683-4

Varley, G.C. \& Gradwell, G.R. (1962). The interpretation of insect population changes. Proceedings of the Ceylon Association of Advancement of Science, 18, 142-156.

Wolfenbarger, D.O. (1954). Potato yields associated with control of aphids and the serpentine leaf miner. Florida Entomologist, 37, 7-12. https://doi.org/10.2307/3492850

Zitter, T.A. \& Tsai, H.J. (1977). Transmission of three potyviruses by the leaf miner Liriomyza sativae (Diptera: Agromyzidae). Plant Disease Reporter, 61, 1025-1029. 